\title{
Elsős mérnökhallgatók véleménye (a szakmáról, a szakmai erkölcsről és a mérnöki etika tárgyról)
}

\author{
É. BuJALOSNÉ KóCZÁN \\ Debreceni Egyetem Műszaki Kar, Műszaki Menedzsment és Vállalkozási Tanszék, beva@eng.unideb.hu
}

Absztrakt. A müszaki felsőoktatásba érettségi után bekerülő hallgatók már rendelkeznek valamilyen elképzeléssel a mérnöki szakmáról, a helyes mérnöki magatartásról, és a saját alkalmasságukról. Az első felmérésem kérdései a hallgatói tanulmányok kezdetekor ezekre a témákra irányultak. A második felmérést a félév végén készítettem, amikor már a kötelezően oktatott mérnöki etika tantárgy ismereteit elsajátították. A hallgatói válaszok azt mutatják meg, hogy mennyiben segítette elö ennek a tárgynak az oktatása azt, hogy jobb mérnökké válhassanak a diploma megszerzése után.

\section{Bevezetés}

Az oktatásban - bármely tantárgy oktatásáról is legyen szó - mindig meg kell válaszolnunk azt a kérdést, hogy honnan hová akarjuk a tananyag segítségével eljuttatni a befogadókat. A tanulmányban ezt szeretném bemutatni a mérnöki etika tárgy kapcsán. A műszaki felsőoktatásban e tantárgy oktatásának az a célja, hogy a fiatal diplomásokból minél jobb mérnök válhasson. A hallgatói véleményeket kérdőívek segítségével ismertem meg. A lehetőséget a felmérésekre az adta, hogy a Természettudományi és Technológiai Karon a vegyészmérnök szakosok számára a mérnöki etika tárgy kötelező tantárgy, és az első félévben oktatandó. A szakon a nappalis évfolyam hallgatói létszáma elég magas, 80 fő feletti, így a mintavétel viszonylag nagy számon alapulhatott.

Az első felmérés az első órán, 2016. 09.20.-án, a második pedig az utolsó órán, tehát 2016.12.13-án készült. A hallgatói részvétel az első kérdőív kitöltésekor 82, míg a második esetén 78 fő volt. Természetesen az írásbeli válaszokat névtelenül adták be a vegyészmérnök szakos hallgatók. Mindkét felmérés kérdezési módszere azonos volt, a feltett kérdésre magától kellett a hallgatónak válaszolnia, tehát segítségként nem támaszkodhatott előre megnevezett "lehetőségekre", amelyekből csak ki kell választania a neki megfelelőt. Természetesen voltak olyan konkrét kérdések is, amelyekre egyesek vagy nem válaszoltak, vagy esetleg kevesebb válaszelemet írtak.

Az első felmérés kérdései arra irányultak, hogy a "gólyáknak" milyen elképzelésük van a mérnöki szakmáról, a jó mérnök tulajdonságairól, és a saját szakmai alkalmasságukról. A második felmérés kérdései segítségével arra kerestem a választ, hogy mennyiben segítette őket a mérnöki etika tárgy abban, hogy végzés után a mérnöki szakmát erkölcsösen művelhessék. 


\section{Az első felmérés eredményei}

\section{1.Ki a mérnök? Határozza meg a mérnök fogalmát!}

Hallgatói válaszok a válaszadók száma alapján:

összesen 82 fő

a.) Műszaki feladatokat megoldó személy:

14 fő

b.)Az iparban gyártási folyamatokat tervező, vezető, felügyelő:

11 fó

c.)Szakirányú felsőfokú diplomával rendelkezik, és műszaki problémákat old meg:9 fő

d.)Természettudományos ismeretekkel, sokféle munkakört betölt az iparon belül: 9 fő

e.)Diplomás szakember, aki az iparban dolgozik:

8 fő

f.) Munkafolyamatot tervező és levezénylő személy

6 fó

g.)Szakember, aki szakterületén belül üzemi és emberi döntéseket hoz:

5 fó

h.)Mérnöki diplomával rendelkező szakember:

5 fő

i.)Hivatás, amely felelősségteljes embert igényel:

4 fő

j.)Technológiai szakember:

2 fó

k.)Felsőfokú diplomával rendelkező szakember, aki magas szintű tudással bír, és

új technológiákat fejleszt ki:

2 fó

1.)Saját tudományterületének ismeretei alapján matematikai számításokat végez: 2 fő

m.)Egyszerű megoldást talál bonyolult problémákra:

2 fő

n.)Az, aki nem csinálja a munkát, hanem kiadja:

1 fö

o.)Nem válaszolt:

2 fó

A mérnöki szakma, vagy hivatás fogalmi definíciója többféle. De mindegyikben közös elemként a következőket találjuk:

A mérnöki tudományokban dolgozó diplomás szakember, aki hivatásszerűen az anyagi javak előállítása során a gazdaságban tevékenykedik. Munkája során a magas szintű természettudományi, matematikai és műszaki ismereteit alkalmazza az új javak (anyagok, gépek, készülékek, folyamatok) létrehozása céljából, egyre magasabb technikai szinten. A mérnök az általa létrehozott javakat vagy tervezi, vagy létrehozza, vagy üzemelteti, vagy müködésüket ellenőrzi, vagy továbbfejleszti. Ez a munka nemcsak magas szintű tudást, hanem sajátos képességeket és attitűdöket is igényel: találékonyság, gyakorlatorientáltság, jó probléma megoldó képesség, nagy felelősségtudat, jó vezetői képesség, csapatszellem.

A 80 hallgató válaszaiból az a következtetés vonható le, hogy alapvetően tisztában vannak a mérnök feladataival, és munkájának sajátosságaival.

\subsection{Soroljon fel legalább 20 emberi értéket!}

A hallgatók értékrendjét hivatott feltérképezni ez a feladat. Egy meglévő értékrendre támaszkodva alakítjuk ki a mérnöki erkölcsről is az elképzeléseinket. 2003 őszén a Budapesti Müszaki Főiskola 18-20 éves hallgatói között már készült egy ilyen felmérés, 78 fó részvételével. A mintavétel nagysága, és a kérdésre történő válaszadás módszere megegyezett a jelenlegivel. Egyetlen eltérés van a két felmérés 
között, akkor ugyanis a hallgatóknak 10, most pedig 20 értéket kellett felsorolniuk. Nyilvánvaló, hogy egy értéket a hallgatók csak akkor neveznek meg, ha azt fontosnak tartják.

Az adatok feldolgozásakor a hasonló fogalmakat összevontam, kivéve, ha mindkét fogalmat leírta a hallgató. Nézzük először a 2003-as felmérés eredményeit*! [1.]

Az első 20 értéket sorrendben mutatom be, a többi érték közül csak azokat veszem sorra, amelyek a 2016-os felmérésben is előkerültek. Természetesen az első 20 érték mellé feltüntettem a 2016-os első 20 értéket. Ez a megoldás teszi lehetővé a felmérések összehasonlítását.

$$
\text { 2003. * (78 fö) }
$$

1. Család

2. Barátság

62 fó

3. Egészség

57 fő

4. Becsület

5. Szeretet

41 fó

33 fő

28 fő

6. Tudás

27 fő

7. Pénz

26 fő

8. 8-9. Szerelem

20 fő

9. 8-9. Vidámság, humor

20 fő

10. 10-11. Barátnő, társ

18 fő

11. 10-11.Tisztelet, megbecsülés 18 fő

12. 12-13. Boldogság

17 fő

13. 12-13. Munka, munkahely 17 fő

14. 14-16. Békesség, nyugalom 15 fő

15. 14-16. Egzisztencia

15 fó

16. 14-16. Őszinteség, egyenesség 15 fő

17.17-19. Autó, motor

14 fő

18.17-19. Sport, verseny

14 fő

19.17-19.Szórakozás,szabadidő, 14fő hobbi

20.Igazságosság, korrektség

13 fő

Kitartás, helytállás, kötelesség

Hit, vallás

12 fó

11 fő

Szabadság

11 fó

Bizalom

8 fó

Megbízhatóság, pontosság

Tisztesség, morál

8 fő

7 fő

Együttérzés,megértés 6 fó

5 fő

Segítőkészség
2016. (80 fö)

$\begin{array}{lr}\text { Család } & 58 \text { fő } \\ \text { Barátság } & 57 \text { fó } \\ \text { Szeretet } & 44 \text { fó } \\ \text { Tudás ! } & 41 \text { fó } \\ \text { Becsület } & 36 \text { fő } \\ \text { Kitartás ! } & 34 \text { fó } \\ \text { Önzetlenség } & 33 \text { fó } \\ \text { Szerelem } & 31 \text { fó }\end{array}$

Segítőkészség ! ! 30 fő

Egészség ! ! 29 fö

Bizalom ! 28 fó

Pénz 25 fö

Határozottság ! ! 24 fő

Erkölcs ! ! 22 fó

Boldogság 22 fö

Tisztelet 21 fö

Öszinteség 21 fő

Megértés ! $\quad 20$ fő

Vidámság, humor 20 fő

Igazságosság 18 fő

Hit, vallás 11 fő

Szabadság 12 fő

Megbízhatóság, pontosság ！ 23 fő 


\begin{tabular}{|c|c|c|c|}
\hline Összetartozás, tolerancia & 8 fő & Összetartozás, alkalmazkodás! & 26 fő \\
\hline Felelősségvállalás & 1 fő & Felelősségvállalás $\quad !$ & 8 fő \\
\hline Kreativitás & 1 fő & Kreativitás & 15 fó \\
\hline
\end{tabular}

A válaszok elemzésekor ne felejtsük el, hogy 2003-ban csak max. 10 választ adhattak erre a feladatra a hallgatók, 2016-ban pedig max. 20-at. Az arányeltolódásokat viszont így is észre lehet venni, ezeket felkiáltójellel jelöltem.

2003-hoz képest csökkent az egészség, és nőtt a tudás jelentősége a hallgatói értékek között.

2016-ban a mérnökhallgatók számára a kitartás, a segítőkészség, a bizalom, a határozottság, az erkölcs, a megértés, a megbízhatóság és pontosság, az összetartozás és alkalmazkodás, a kreativitás, valamint a feleloosségvállalás sokkal nagyobb érték, mint 2003-ban volt. Ez azért jelent pozitív elmozdulást, mert a helyes mérnöki magatartásban fontosak ezek az értékek.

\section{3. Ön szerint mely tulajdonságok jellemzik a jó mérnököt?}

Csak az első 20 választ sorolom fel, a válaszok számát feltüntetve. (2016. 09.20. 80 fó)

\begin{tabular}{|c|c|c|c|c|}
\hline 1. & Precíz, pontos, alapos & 57 fö & 11. Továbbképzési igény & 17 fő! \\
\hline 2. & Kreatív, jó problémamagoldć & ó 32 fő & 12. C sapatszellem & 16 fő! \\
\hline 3. & Magasszintű szaktudás & 28 fő! & 13. Becsületesség & 13 fő \\
\hline 4. & Okos, logikus gondolkodás & 25 fő & 14. Elhivatottság & 14 fő! \\
\hline & Kitartó & 23 fő & 15. Felelősségtudat & 14 fő! \\
\hline 6. & Találékony, talpraesett & 23 fó & 16. Magabiztosság & 14 fő \\
\hline & Erkölcsösség & 18 fő! & 17. Fegyelmezettség & 13 fő! \\
\hline & Megbízhatóság & 17 fő! & 18. Türelem & 12 fő \\
\hline & Segítőkészség & 17 fő! & 19. Alkalmazkodó képess & 12 fő \\
\hline & Határozottság & 17 fő! & 20. Jó irányítási képesség & 11 fö! \\
\hline
\end{tabular}

Ezek a válaszok azt mutatják, hogy a hallgatók döntő része a tanulmányai kezdetekor nincs tisztában azzal, hogy a jó mérnöknek milyen tulajdonságokkal kell rendelkeznie. Az kevés, hogy precíz, pontos, alapos legyen! Az elborzasztó szélsőséget az jelenti, hogy 80 főből csak 1-1 hallgató írta be a versenyszellemet, az igazságosságot, vagy az optimista szemléletet, mint pozitív mérnöki tulajdonságot!

\subsection{Sorolja fel, milyen egyéni tulajdonságai teszik önt alkalmassá a mérnöki munkára!}

Az első 20 választ ismertetem a hallgatói válaszokból ((2016. 09.20. 80 fő) 


\begin{tabular}{|c|c|c|c|}
\hline 1.Pontos, precíz, alapos & 41 fő & 11. Magabiztosság & 13 fő \\
\hline 2.Jó problémamegoldó k. & 27 fő & 12. Becsületesség & 13 fő \\
\hline 3. Csapatszellem & 25 fő & 13. Jó kommunikác iós k. & 12 fó \\
\hline 4. Kitartás & 24 fő & 14. Türelmesség & 11 fő \\
\hline 5. Tudás & 18 fő ! & 15. Erkölcsösség & 10 fő! \\
\hline 6. Tájékozottság & 18 fő & 16. Segítőkészség & 10 fő \\
\hline 7. Szorgalom & 18 fó & 17. Megfontoltság & 10 fö \\
\hline 8. Továbbképzési igény & 14 fő & 18. Megértő & 10 fő \\
\hline 9. Elhivatottság & 14 fö & 19. Jó munkamorál & 10 fő \\
\hline 10. Megbízhatóság & 13 fő & 20. Felelősségtudat & 10 fő \\
\hline
\end{tabular}

Amely erényeknek a mérnöki munkában fontosságot tulajdonít a hallgató, azokat az erényeket keresi önmagában is.

Bár a precizitást elfogadhatóan sokan tartják fontosnak a mérnöki munkában (57 fô), viszont lényegesen kevesebben (41 fó) tartják magukat precíznek, alaposnak. A felsőoktatásban ezért mindenképpen fontos erősíteni ezt a készséget. Sajnos a problémamegoldó készség, a csapatmunkára való alkalmasság, a kitartás, a tudás, a tájékozottság, valamint az erkölcsösség-becsületesség (összesen 23 fő tartja magát ilyennek) terén is az látszik, hogy ezekkel a tulajdonságokkal kb. csak a hallgatók egyharmada-egynegyede rendelkezik. Az igazi nagy probléma azonban ott van, hogy 14- 10 fö közötti a száma azoknak, akik magukat továbbképzésre vágyónak, a mérnöki szakma felé elhivatottnak, megbízhatónak, magabiztosnak, jól kommunikálónak, türelmesnek, segítókésznek, megfontoltnak, megértőnek, munkaszeretőnek, és felelősségtudatosnak tartják! Ezekhez a képességekhez és attitűdökhöz a képzés során a humán tárgyak oktatása, valamint a mérnöki etika tárgy oktatása (lásd felelősségtudat!) juttatja el a leendő mérnököket. Egyet kell értenünk néhai Pattantyús Ábrahám Géza műegyetemi professzorral, aki szerint a mérnöki "hivatás felelősségteljes gyakorlásához az alapos szaktudáson felül széles látókörre, erkölcsi érzékkel párosult jellemerőre és felelősségtudatra van szükség".[2.]

A képzést folytató intézménynek a jelenlegi közoktatási helyzet mellett ez különösen nagy kihívást jelent! A döntéshozók felelősségét pedig növeli, amikor a kari tanácsokban a konkrét tanterveket megszavazzák a kormányrendeletekben rögzített szakmai képzési és kimeneti követelményekhez igazítva!

\section{A második felmérés eredményei:}

Ez a felmérés a félév utolsó előadásán, 2016. 12.13.-án készült, 78 hallgató részvételével. A 78 hallgatóból csak 74 fő adta be a kérdőívet. Összesen 6 kérdésre kellett válaszolniuk. A kérdések arra irányultak, hogy képet kapjak a mérnöki etika tárgy oktatásának hasznosságáról.

\subsection{Gyarapodtak-e jelentősen az ismeretei a mérnöki szakmáról a mérnöki etika tárgy oktatása során?}


A válaszok megoszlása a következő volt:

- Jelentősen gyarapodtak: 55 fő

- Gyarapodtak, de nem jelentősen: 12 fő (az esettanulmányok miatt)

- Nem gyarapodtak:

7 fó

A válaszokból egyértelműen látszik, hogy van értelme a tárgy oktatásának, mert általa a hallgatók $a$ mérnöki szakmát, tehát a leendő foglalkozásukat jobban megismerték.

\subsection{Növekedett-e önben a mérnöki felelősségtudat a tárgy hatására?}

A válaszok megoszlása a következő volt:

- Növekedett: 60 fó

- Nem jelentősen, de nőtt: 1 fő

- Nem növekedett: 13 fő

Az önbevalláson alapuló válaszok szerint szinte alig rendelkeznek (lásd 1. felmérés 4-es feladat, 10 fő) a leendő mérnökök felelősségtudattal, ezért nagyon fontos, hogy a félév során a tananyag segítségével nôtt a felelösségtudata a müszaki hallgatóknak.

2.3. Jelölje meg 1-10-ig skálán, a legkönnyebbtől a legnehezebb felé haladva azt, hogy ön szerint a gyakorlati életben mennyire lehet érvényre juttatni a mérnöki etika értékesnek tartott normáit!

A válaszok megoszlása a következő volt.

1-es számot 1 fő

2-es számot 3 fó

3-as számot 3 fó

4-es számot 4 fö

5-ös számot 6 fö

6-os számot 8 fő

7-es számot 20 fő

8-as számot 17 fő

9-es számot 8 fó

10-es számot 2 fő

nem írt számot 2 fó 
A válaszok alapján megállapítható, hogy az átlagostól sokkal nehezebben érvényesíthetőnek tartják a hallgatók az erkölcsös magatartást a mérnöki munkában, ami azt jelenti, hogy a fennálló viszonyokat nem tarthatjuk “ideálisnak", mert még ha akarnának, akkor sem tudnának könnyen erkölcsös mérnökként tevékenykedni.

A válaszolók közül 30 fő okokat is írt, amely magyarázatok önmagukért beszélnek. Például: az erkölcstelenség jellemző az előrejutásban; sok embernek nincs stabil értékrendje; az érdekek és az értékek ütköznek; sok tényező befolyásolja a döntéseket; csak a gazdasági fejlődés a fő cél; stb. hivatás erkölcsös művelését. $A$ hallgatók jelentős része jól látja azokat a negatív körülményeket, amelyek megnehezítik a mérnök erkölcsös viselkedését.

\subsection{Akar-e változtatni a külső körülményeken azért, hogy minél erkölcsösebben gyakorolhassa a mérnöki szakmát?}

A 74 hallgatói válasz a következő megoszlású:

- Változtatna

- Nem változtatna:

- Nem hiszem, hogy képes lennék változtatni: 1fő

- Talán igen, de nem igazán látok bele: 1fó

A hallgatók 2/3-a úgy gondolja, hogy a fennálló viszonyok változtatásra szorulnak, és életkoruknak megfelelően hajlandóak is erre.

\subsection{Ha változtatna, mit változtatna, ha nem, akkor miért nem változtatna? Kérem, indokoljon!}

A változtatni szándékozó 44 fő indokai a következők voltak:

- Barátias munkahelyi környezet, fejlettebb technika szükséges 5 fő

- Erősebb motiváció kell az erkölcsös viselkedéshez: 5 fő

- Nyereségorientáltság helyett erkölcs orientáltság kell: 4 fó

- Növelni kell az elhivatottságot: 3 fő

- Növelni kell a béreket a korrupció csökkentéséhez: 3 fő

- Szigorítani kell a mérnökké válás feltételén: 2 fő

- Változtatni kell a támogatásokon: 2 fő

- Csak erkölcsös mérnököt tartsanak jó mérnöknek: 2 fő

A többi választ 1-1 fő adta, de felsorolom őket, mert érdekesek:

A politika ne hasson a mérnöki munkára az önös érdekeivel; megváltoztatnám a kollégáimat; csökkenteni kell a gazdasági igazgatók beleszólását; kisebb legyen a munkahelyeken a társadalmi megkülönböztetés; jobban megismerni a gyakorlati életet; több időt fektetni egy-egy munkába; 
jobbítani a világon, ha kevesebb erkölcstelen élne benne; több ellenőrzéssel csökkenteni a jogellenes magatartást; kijavítani az elkövetett hibákat; keményebb szankciók bevezetése; bevezetni a mérnöki etika oktatását minden műszaki felsőoktatásban; elköltöznék külföldre; egy erkölcsös környezet biztonságosabb; csökkenteni a pénz iránti vágyódást; a jó erkölccsel embernek érezhetném magam; félelemből és ne szabad akaratból cselekedjenek!!!!; kitoloncolni a cigány munkanélkülieket, és bérüket a mérnököknek adni!!!!!

A felsorolt indokokból levonható az a következtetés is, hogy sokan azt is helyesen látják, hogy milyen körülményeken kellene változtatni.

Annak a 28 főnek, akik nem akarnak változtatni, a következő indokaik voltak:

- Nem változtatnék, mert erkölcsös vagyok:

- Nem változtatnék, mert nincs szükség rá:

- Tapasztalat híján nem tudok válaszolni:

- Mindenkinek magának kell erkölcsösnek lennie:

- A mérnöki etika tárgy elég a szakmai erkölcs elsajátításához 2 fő

- Egy fecske nem csinál nyarat:

2 fó

- Nem indokolt

A többi választ 1-1 fő adta, de felsorolom őket, mert érdekesek:

Nem akarok erkölcsös lenni; mert az emberek úgy sem változtatnak a saját gondolkodásmódjukon; most ez a rendszer van, majd idővel megváltozik; az erős gyári hierarchia miatt az állásom kockáztatása helyett inkább a pénzt választom; ha változtatnék, azzal mások érdekeit sérteném; az erkölcs nem változtatható meg; akik megszegik a szabályokat, később is meg fogják szegni.

A válaszok azt mutatják, hogy néhány hallgató antiszociális személyiségű, de a változtatás igényéről való lemondás inkább a pesszimista életszemléletből fakad.

\subsection{Szeretne -e példamutató erkölcsű mérnökként dolgozni és élni?}

A 74 válaszoló közül 71 fő igent, és 3 fő nemet válaszolt a kérdésre.

Ez az arány azt mutatja, hogy a leendő mérnökök számára az erkölcsösség érték, pozitívan viszonyulnak hozzá, és elkérendő célnak is tartják.

Mindenkinek, aki a képzésük során kapcsolatba kerül velük, ez egy jó alap és kapaszkodó lehet. Valószínűleg ezzel magyarázható az is, hogy a mérnöki etika tárgyat fontosnak tartják. A félév folyamán nemcsak elméleti ismeretekre tettek szert, hanem esettanulmányok segítségével felkészültek arra, hogy hogyan kell a mindennapokban mérnökként az erkölcsi értékeknek megfelelően dönteni és cselekedni. Ez az igazi nagy kihívás! A nagy kérdés mindig az, hogy hol vannak az önérdekünk korlátai. Fromm, aki egy életközpontú erkölcsöt hirdet, szentül hiszi, hogy a más lények iránti törődés, beleértve az embereket, a természeti lényeket, és a jövő generáció tagjait, kijelölik a helyes cselekvések mezsgyéit. [3] 


\section{3. Összegzés}

A hallgatók pozitív viszonyulása az erkölcsösséghez nagyon fontos a társadalom számára. A közgazdaságtan egyik hazai kiválósága, Kopátsy Sándor ezt így fogalmazta meg: "ha van megfelelő morál, akkor ott a viszonylag gyenge és sok hibás jogi keret és útját tévesztett gazdaságpolitika mellett is biztosan jönnek a gazdasági eredmények, ahol pedig hiányzik a morál, semmilyen jog nem hozhat eredményeket"[3.]

A mérnöki erkölcsösségnek a gazdasági hasznosságát vizsgálva vissza kell térni az alapokhoz, amelyet Max Weber jelent. Ő általában beszélt arról, hogy a protestáns etika, amely a kemény munkát, a szorgalmat, a türelmet, a fegyelmezettséget és a kötelezettségek betartását biztosító kötelességtudatot, tehát a pozitív erkölcsi magatartást várja el az embertől, tette lehetővé a kapitalizmus kialakulását [4.], alapozta meg a gazdasági és technikai fejlődést.

A tőkés gazdaság kialakulásában és müködtetésében is nagy szerepe van az erkölcsnek! A mérnöktársadalom is érzi ezt, ezért alkották meg a Mérnöki Etikai Kódexet a Mérnöki Kamarában. Vannak azonban olyan etikai normák is, melyek követése profitcsökkenéssel jár. Sen jó példát hoz erre a problémára. Szerinte a környezetvédelem területén a piac szereplői előszeretettel alkalmazzák a környezetszennyezést, mert ez gazdasági előnyt hoz számukra. [6.] Azért szükséges egy stabil etikai értékrend a mérnök számára, mert megkönnyíti a helyes döntést és cselekvést az ilyen helyzetekben.

Örülök neki, hogy mérnöki etika tárgy oktatásával jelentősen hozzájárulhatok ehhez.

\section{Hivatkozások}

[1.] Legeza László Mérnöki etika Akadémia-Mikes Kiadó Budapest 2004. 18-20.

[2.] Legeza László Mérnöki etika Akadémia-Mikes Kiadó Budapest 2004. 8.

[3.] Erich Fromm “Önzés, szeretet, önérdek" in. Kindler J. és Zsolnai L. (szerk.):"Etika a gazdaságban”Kereban Kiadó Budapest 1993.15-25.

[4.] Kopátsy Sándor Gazdasági jog-gazdasági morál in: Magyar Tudomány, Akadémia Kiadó és Nyomdai Vállalat Budapest 1993. 8. szám 977

[5.] Max Weber A protestáns etika és a kapitalizmus szelleme Gondolat Kiadó Budapest 1982.

[6.] Amartya Sen A fejlődés mint szabadság Európa Kiadó Budapest 2003. 401. 